\title{
LATVIJAS SEGAS LATVIJAS TŪKSTOŠGADEI
}

\author{
Inese Sirica, Dr. art., Rauls Vēliņš
}

Latvijas simtgadei par godu ir izdota grāmata Latvijas segas Latvijas tūkstošgadei ([2018) Rīga : Sana Solaris). Grāmatā interesentiem ir unikāla iespēja iepazît vēl mūsdienās aktīvo un reizē seno Latvijas tautas amatniecības tradīciju - aušanu. Vienos vākos ir apkopotas visos Latvijas novados vēl arvien strādājošo audēju darinātās segas. Zinātnisku skanējumu pieškiir vairāki oriğinālpētījumi: Dr. hist. Uǵis Niedre sniedz ieskatu Vecpiebalgas audēju darbā, Dr. art. Inese Sirica izveidojusi apskatu par aušanas tradīcijas attīstību Latvijā no 19. gs. beigām līdz mūsdienām, savukārt Zane Ulmane aprakstījusi Latgales un Vidzemes segu attīstības vēsturi un īpatnības. Smaida Rubeze ieskatījusies Kurzemes segu rakstos un lūkojusi atrast kopīgo un atšķirīgo latviešu, lībiešu, suitu un ķoniņu segās. Aušanas mitolog̣isko skanējumu atklāj Dr. philol. Janīna Kursīte.

Grāmatas idejas autors ir ārsts Rauls Vēliņš, kuram interese par austajām segām nāk no vecvecmammas Alīdas Āboliṇš dāvinātās zvaigžņu segas meitām Emmai, Zelmai un
Elzai Stāmerienas pagasta Pḷavenieku mājās. Vēlāk, turpinot tradīciju, vecvecmammas austās segas atdarināja prasmīgās Staiceles audējas, lai varētu formās senatnīgās segas dāvināt tālāk bērniem kopā ar stāstu par dzimtu. Tomēr doma par grāmatu, kas veltīta Latvijas segām, radās 2016. gada Ziemassvētku laikā, apmeklējot tautas lietišķās mākslas izstādi Kuldīgā, ko organizēja Latvijas Nacionālais kultūras centrs. Izstādē vienuviet bija skatāmas mūsdienu audēju austās Latvijas novadu segas - tā arī sauc izstādi.

Lielā mērā ar aušanas studiju vadītāju atbalstu grāmatas tapšanas laikā tika aptaujātas aptuveni 250 audējas no 60 audēju studijām. Par katru segu tika aizpildīta anketa, kas atspogulo steḷıu veidu, segas aušanas tehniku, materiālu, izmēru, aušanas laiku. Audējām tika lūgts uzrakstīt arī segas stāstu vai jēgu, kas izdevumu padara īpaši interesantu. Grāmatā sevišşi izcelti aptaujas rezultātā noskaidrotie skolotāji. Izdevumā ir lasāma katras studijas īsa vēsture un konstatēts studijā esošo audēju un steḷıu skaits.

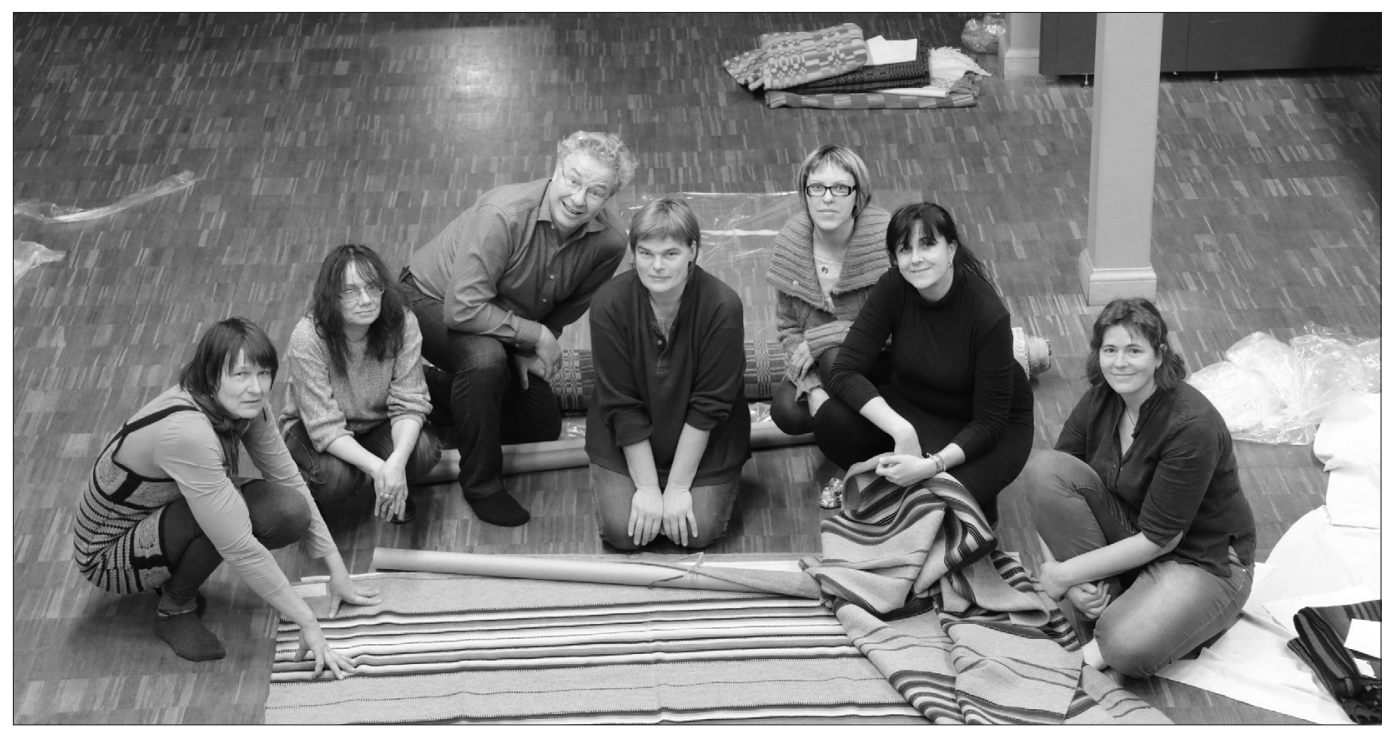

Segu fotografēšana Kuldīgā (centrā - Rauls Vēliņš) 
Vairāk nekā 500 segu fotogrāfiju atspogul̦o Latvijas audēju veikumu. Vēsturisko segu paraugi iegūti Baltinavas novada muzeja, Balvu novada muzeja, Cēsu Vēstures un mākslas muzeja, biedrības Etniskais kultūras centrs Suiti, Indras aušanas darbnīcas, Kolkas līvu centra Kūolka, Latgales Kultūrvēstures muzeja, muzeja un pētniecības centra Latvieši pasaulē, Latvijas Etnogrāfiskā brīvdabas muzeja, Latvijas Nacionālās bibliotēkas, Liepājas muzeja, Preiḷu vēstures un lietišḳās mākslas muzeja, Rojas Jūras zvejniecības muzeja, Tukuma muzeja, Viḷānu novadpētniecības muzeja un Latvijas Nacionālā vēstures muzeja kolekcijās. Palīdzīgu roku snieguši arī privātkolekcionāri un draugi.

Izdevums Latvijas segas Latvijas tūkstošgadei paredzēts ne tikai mūsdienu lasītājiem un interesentiem, bet arī nākamajām paaudzēm kā aicinājums saprast, novērtēt, turpināt un radīt. Aušanas prasmes ir gadu simtiem pārmantotas, arī mainītas atbilstoši jauniem estētiskiem kritērijiem. Krišjānis Barons vāca dainas, savukārt izdevuma autoru uzdevums ir bijis vākt un padarīt zināmas mūsu tautai tik nozīmīgās aušanas tradīcijas. Dainu skapis ir izcils paraugs, kā izveidot segu un citu materiālo kultūras liecību digitālu krātuvi.

Novērtējot nesavtīgo mūsdienu audēju darbu, ceram, ka radīsies arvien jaunas tautas lietišķās mākslas studijas, tautas lietišķās mākslas meistari un tiks atjaunota šī statusa piešķiršana. Audējas veiktajās aptaujās bieži norādīja, ka meistara nosaukums ir pagodinošs un uz mācīšanos vērsts statuss.

Austajām Latvijas novadu segām, audējām un aušanas tradīcijām veltîtā grāmata veicinās ǵimenes godos novērtēt esošās un radīt jaunas segas. Jau tagad ir gimenes, kuras dzimtu saietos var lepoties ar senām segām un lepni sacīt: "Šì ir manas dzimtas svētku sega.” Mums ir cerības, ka jaunā paaudze novērtēs Latvijas segas un pasūtīs tās pie audējām māju interjera izdaiḷošanai.

Latvijas piemērs tautas amatniecības mantojuma saglabāšanā var palīdzēt citām tautām sekot mūsu piemēram. Esam unikāli ar daudzajām tautas lietišķās mākslas studijām, kurās vēl joprojām tiek darinātas lietas - arī segas -, balstoties uz tautas mākslas amata prasmēm, citreiz tās radoši attīstot. Spēcīgais tautas lietiškās mākslas studiju tīkls, kurā pašvaldības finansē saimnieciskos izdevumus un Latvijas Nacionālais kultūras centrs sniedz atbalstu mākslinieciskās un profesionālās izglîtības jomā, veicina aušanas tradīciju turpināšanu. Tādas studijas kā Riekums un Ulbroka ir atradušas saikni ar vispārizglītojošām skolām.

Grāmata ir aicinājums arī Aizsardzības ministrijai atjaunot tradīciju un dāvināt "karavīra segu" katram Latvijas karavīram un katram atbraukušajam citu draudzīgo valstu karavīram kā pateicību par mūsu valsts aizstāvību.

Grāmata ir pārliecinoša un cienīga mūsu valsts reprezentācijas dāvana. Mums ir cerība, ka grāmata būs impulss jaunu, vēl labāku darbu veidošanā.

\section{MONOGRĀFIJA PAR LATVIJAS ZEMI, DABU, TAUTU, VALSTI}

Ol̦ǵgerts Nikodemus, Dr. geogr., Māris Kḷaviņš, Dr. habil. chem., Zaiga Krišjāne, Dr. geogr., Vitālijs Zelčs, Dr. geol., LU profesori

Monogrāfijā Latvija. Zeme, daba, tauta, valsts ([2018] Rīga : LU Akadēmiskais apgāds) apkopota jaunākā zinātniskā informācija par Latvijas teritoriju, geologiju, klimatu, ūdeņiem, augsni un biotu, iedzīvotājiem, saimniecību, teritorijas attīstību, ainavām, dabas daudzveidību un kultūrvēsturisko mantojumu un tā aizsardzību, kā arī priekšnoteikumiem 